\title{
Pollinator-mediated self-pollination and reproductive assurance in an isolated tree of Magnolia grandiflora L.
}

\author{
Arun Sukumaran, Vinod Prasad Khanduri (iD and Chandra Mohan Sharma
}

\begin{abstract}
Background: The ability to produce seeds when pollinators or potential mates are scarce is one of the principal advantages of self-pollination in flowering plants. However, the role of pollinators mediating self-pollination to ensure seed set when pollen or potential mates are limited has received less attention. This study examined the reproductive consequences and involvement of pollinators in assuring seed set in an isolated tree of Magnolia grandiflora, a predominantly outcrossing species.
\end{abstract}

Methods: We tested various aspects of reproduction such as flower density, floral rewards, stigma receptivity, pollinator abundance and behaviour, fruit set and seed set, in two successive reproductive years (2015-2016).

Results: Flowers of M. grandiflora possess a suite of traits facilitating pollinator-mediated self-pollination (PMS), although the chances of autonomous self-pollination are reduced due to herkogamy, spatial separation of anther and stigma. The mean pollen production/flower was 5,152,289 $\pm 285,094$ with a pollen-to-ovule ratio of $39430 \pm$ 164. We found a significant positive correlation between number of visits and seed production for bees $(r=0.5099$, $p=0.0007)$ and beetles $(r=0.7159, p=0.00001)$, indicating these are effective at PMS. There was a significant negative correlation for thrips $(r=-0.3206, p=0.044)$ and no correlation for flies or spiders. The percent fruit set was $100 \%$ and the seed set per ovule ranged between 19 and $20 \%$.

Conclusions: PMS will guarantee reproductive assurance and mitigate the effect of reduced mates or pollen limitation which is expected to increase the fecundity and establishment of individual trees in geographically isolated locations.

Keywords: Pollinator-mediated self-pollination, Magnolia grandiflora, Autonomous self-pollination, Pollinator behaviour, Reproductive assurance

\section{Background}

Since the time of Darwin (1876), researchers have been interested in why there are plants that are primarily selffertilizing even though the progeny produced by selffertilization (whether of normally outcrossing or normally selfing plants) are often less vigorous than progeny produced by cross-fertilization. Stebbins (1950) stated that the ecological conditions in which a given

\footnotetext{
* Correspondence: khandurivp@yahoo.com

College of Forestry, VCSG Uttarakhand University of Horticulture and Forestry, Ranichauri, Tehri Garhwal, Uttarakhand 249199, India
}

species is found are supposed to determine whether it is predominantly self-fertilized or predominantly outcrossed. A high proportion of self-compatible species (or populations) are found in isolated locations (e.g. oceanic islands, isolated ponds; Baker 1955; Longhurst 1955). Self-pollinating morphs would be favoured by natural selection when population size or potential mates are limited.

Hermaphrodite and monoecious species have the potential for self-pollination leading to self-fertilization unless there is a mechanism to avoid it. This self-pollination consists of pollen transfer within one flower (autogamy) as well as

\section{Springer Open}

( ) The Author(s). 2020 Open Access This article is licensed under a Creative Commons Attribution 4.0 International License, which permits use, sharing, adaptation, distribution and reproduction in any medium or format, as long as you give appropriate credit to the original author(s) and the source, provide a link to the Creative Commons licence, and indicate if changes were made. The images or other third party material in this article are included in the article's Creative Commons licence, unless indicated otherwise in a credit line to the material. If material is not included in the article's Creative Commons licence and your intended use is not permitted by statutory regulation or exceeds the permitted use, you will need to obtain permission directly from the copyright holder. To view a copy of this licence, visit http://creativecommons.org/licenses/by/4.0/. 
pollen transfer between different flowers on the same tree (geitonogamy). Selfing plants benefit from two distinct advantages over their outcrossing competitors (Charlesworth 2006; Barrett 2002). First, because selfers are $100 \%$ related to their progeny and can also act as outcross pollen donors for seed produced by other individuals, they have an inherent transmission advantage over outcrossers (Fisher 1941). A second major advantage conferred by selfing, first discussed by Darwin (1876), is the ability to reproduce when pollinators or potential mates are limited (reproductive assurance). One important aspect of reproductive assurance is the ability of selfing lineages to colonize new habitats from a very small founding population. In general, selfing should provide reproductive benefits whenever the pollination environment (availability of mates and/or pollinators) is poor (Lloyd 1979).

Pollinators can mediate self-pollination by foraging within flowers (facilitated selfing) or between flowers on the same plant (geitonogamy). Reproductive assurance may result from both autonomous selfing and, to a lesser extent, facilitated selfing (Lloyd and Schoen 1992; Vaughton and Ramsey 2010). However, when pollinators are missing, only autonomous self-pollination may provide reproductive assurance (Lloyd 1992). Facilitated selfing, on the other hand, only provides reproductive assurance when mates are scarce, but generally not when pollinators are limiting. Moreover, because facilitated and geitonogamous selfing occurs at the same time as outcrossing, discounting costs can be incurred, particularly following geitonogamy. Accordingly, these selfing modes are regarded as non-adaptive consequences of attracting animals that cross pollinate flowers (Lloyd 1992; de Jong et al. 1993; Harder and Barrett 1995; Eckert 2000).

Magnolia grandiflora (Magnoliaceae) occurs within the relatively ancient order Magnoliales. Until the end of the last century, biologists considered Magnoliales to be among the oldest flowering plants with the estimated date of emergence of the order around 95.5 million years ago, and they are now considered ancient but distinctly specialized flowering plants (Losada 2014). Being a primitive plant among angiosperms, the flowers of Magnolia are measured as a theoretical starting point for understanding the evolution of angiosperms (Cronquist 1981). M. grandiflora is a medium-sized evergreen tree, mostly distributed over East Asia, Central America and North America. Magnolia encourages cross-pollination and is specifically adapted to beetle pollination (Allain et al. 1999; Baker and Hurd 1968; Gibbs et al. 1977; Ishida 1996; Dieringer et al. 1999). The seed set following natural pollination in various species of Magnolia is reported to be low, i.e. 8.7\% for M. stellata (Hirayama et al. 2005), 13-25\% for M. hypoleuca (Kikuzawa and Mizui 1990), 16.97\% for M. sinica (Chen et al. 2016), 34\% for M. grandiflora (Allain et al. 1999) and $14.7 \%$ for M. officinalis, $14.8 \%$ for M. kobus and 39\% for M. obovata (Kameneva and Koksheeva 2013).
However, controlled cross-pollination resulted to comparatively high seed set, which varied between 31.77 and 43.3\% (Chen et al. 2016; Allain et al. 1999; Hirayama et al. 2005). Here, our specific objectives were to explore (1) floral characteristics and pollinator rewards in M. grandiflora, (2) how isolation (absence of potential mates) affects pollinator availability and reproductive success and (3) the effect of pollinator-mediated self-pollination (PMS) on reproductive assurance. Our approach will provide a detailed examination of the reproductive aspects associated with pollinator-mediated self-pollination (PMS) or facilitated self-pollination in an isolated tree.

\section{Methods}

\section{Study site}

The investigation was carried out in an isolated tree of M. grandiflora, which was located at the College of Forestry, V.C.S.G. Uttarakhand University Horticulture and Forestry, Ranichauri, Tehri Garhwal (Latitude $30^{\circ} 18^{\prime \prime}$ $\mathrm{N}$, Longitude $78^{\circ} 24^{\prime \prime} \mathrm{E}$, altitude $1800-2000 \mathrm{~m}$ amsl), Uttarakhand, India. The isolated tree was planted in the year 2001 and the seedling was brought from Dehradun; a survey has been carried at a distance of more than 15 $\mathrm{km}$ in the surrounding zone of the local tree and ensured that no other trees are growing or planted. The study was conducted in the month of June to October in 2 successive years 2015 and 2016. During the study period, the mean monthly rainfall was $10.47 \mathrm{~mm}$; the average relative humidity was in between 76 and $91.6 \%$. Maximum monthly means of daily temperature ranged from 22.38 (July 2015) to $23.42{ }^{\circ} \mathrm{C}$ (August 2016) and the corresponding minimum was from 17.75 (July 2016) to $17.26^{\circ} \mathrm{C}$ (August 2016). The July and August are the peak rainy season in the study area.

\section{Floral phenology}

Floral characteristics and development were observed in two consecutive reproductive episodes (2015-2016) on selected flowers of $M$. grandiflora. Flower buds were tagged from the bud initiation. Development of the flower was observed daily and each stage was recorded systematically. Floral traits such as colour, shape, size, phyllotaxy, symmetry and numbers were examined and tabulated by close observation. To determine the peak time of anthesis, flowers were observed frequently at regular intervals of the day and correlated with time, temperature and humidity of the day. The opening and closing of each flower during the study period were recorded separately.

\section{Pollen production}

Pollen production per flowers was assessed by noon loop method (Khanduri 2012; Khanduri et al. 2019). Mean pollen production within a tree was determined by using 
the following formulae. $\Sigma \mathrm{TP}=F \times A \times P$, where $\Sigma \mathrm{TP}$ is the total pollen grains per tree, $F$ is the total number of counted flower per tree, $A$ is the average number of anthers per flower and $P$ is the average number of pollen grains per anther.

\section{Stigma receptivity}

The receptivity of the stigma was also tested on flowers with the application of hydrogen peroxide solution in vivo at various time intervals of the day since the first day of flower opening till the end of receptivity. Hydrogen peroxide was poured over the stigma, bubbling indicating peroxide activity and stigma receptivity (Carrington et al. 2003).

\section{Flower visitors and behaviour}

Pollinator observations were carried out throughout the day from the time of the flower opening, in 4 consecutive days between 07:00 and 16:00 $\mathrm{h}$ in different flowers to cover the whole flowering period ( 2 months) in 2 consecutive reproductive years. Insects visiting the inflorescence were observed for their foraging behaviour, the frequency of visiting and relative abundance. Insects that collected pollen and contacted stigmas were recorded as pollinators. Insects that visited flowers were captured using insect trapping net (Sweep net) and polythene bags. The type of flower visitors as well as its behaviour inside the flower was recorded with the help of videotape. Insect visitor data were recorded on an average of $3 \mathrm{~h}$ immediately after the first and second day of the flower opening in twenty-five flowers. Bees were collected and observed under microscopy to explore their pollen capturing behaviour. Insect collection has been conducted from the flowers of selected the trees. Representative specimens of all visitors were collected and brought back for identification.

\section{Pollinator-mediated self-pollination (PMS)}

Reproductive success (percent fruit set) and reproductive potential (seed set per ovule) in an individual tree of $M$. grandiflora are considered to be the result of selfing (autonomous self-pollination where pollination takes place without the participation of external agent or PMS where flower visitors cause some autogamy as well as geitonogamy). The spatial and temporal separation activities of the staminate and pistillate parts of individual flowers act to diminish the possibility of autonomous self-pollination. To determine PMS, a total of 20 flowers each in two flowering seasons were tagged, marked and kept as such in natural conditions and the total number of floral visitors to each flower was recorded individually by manual observation and video recording. The percentage of the reproductive capacity of selected flowers has been estimated and considered the result of pollinator-mediated self-pollination. The efficiency of the insects performing self-pollination was examined by correlating the percentage of ovules that formed seeds (reproductive capacity) obtained from the fruits derived from the selected flowers with the total number of insects per order that visited the flower. Furthermore, reproductive success was estimated by counting the percent of flowers that matured into fruits. Reproductive capacity was assessed through the ratio of the total number of seed output in a tree by total number of ovules in all flowers and expressed in percentage.

\section{Statistical analysis}

Means \pm standard deviation was calculated for all the observed parameters under study. $t$ tests were performed to assess the variability in (1) seed production in the reproductive years 2015 and 2016, (2) mean number of ovule production/flower in 2015 and 2016 and (3) ovule production and seed set. Likewise, Pearson's correlation coefficient was generated to determine relationship between the number of insects per order visited per flower and reproductive capacity (\% of seed/ovule per fruit).

\section{Results}

\section{Pollen production and stigma receptivity}

Flowers contained $331 \pm 6$ stamens, which were whitish in colour, three-veined and contained four microsporangia. Anthers were occupied below the stigmatic cone. Carpels ( $65 \pm 2$ per flower) were spirally coiffed over the cone-shaped receptacle of $6.52 \pm 4 \mathrm{~cm}$ long. The estimated mean number of pollen grains per anther was 15 , $229 \pm 858$ with a CV value of 5.63 and the estimated mean number of pollen grains per flower was 5,152,289 $\pm 285,094$ with the CV of 5.53. The average pollen production for the entire tree in the 2 reproductive years varied from $1.49 \times 10^{8}$ to $1.64 \times 10^{8}$. The estimated pollen-ovule ratio within the flower was $39,430 \pm 1641$ pollen grains per ovule.

M. grandiflora demonstrated a continual flowering habit (flowering with sporadic brief breaks) for a period of 3 months and dianthesis (each flower opened twice). Upon opening, flowers were functionally female, with receptive stigma producing nectar like exudates (Fig. 1a). Dehiscence of anthers was witnessed from the second day of flower opening and a flower took around 5-6 h for complete anther dehiscence (Fig. 1b). The life span or viability of an individual flower varied considerably ranging from 3 to 4 days, after which they began to turn brown and senesce. Flower buds were often initiated in the last week of June and fruit fully ripened in September-October. The various stages in reproduction and average time duration from flower bud initiation in days were recorded (Table 1 ). 


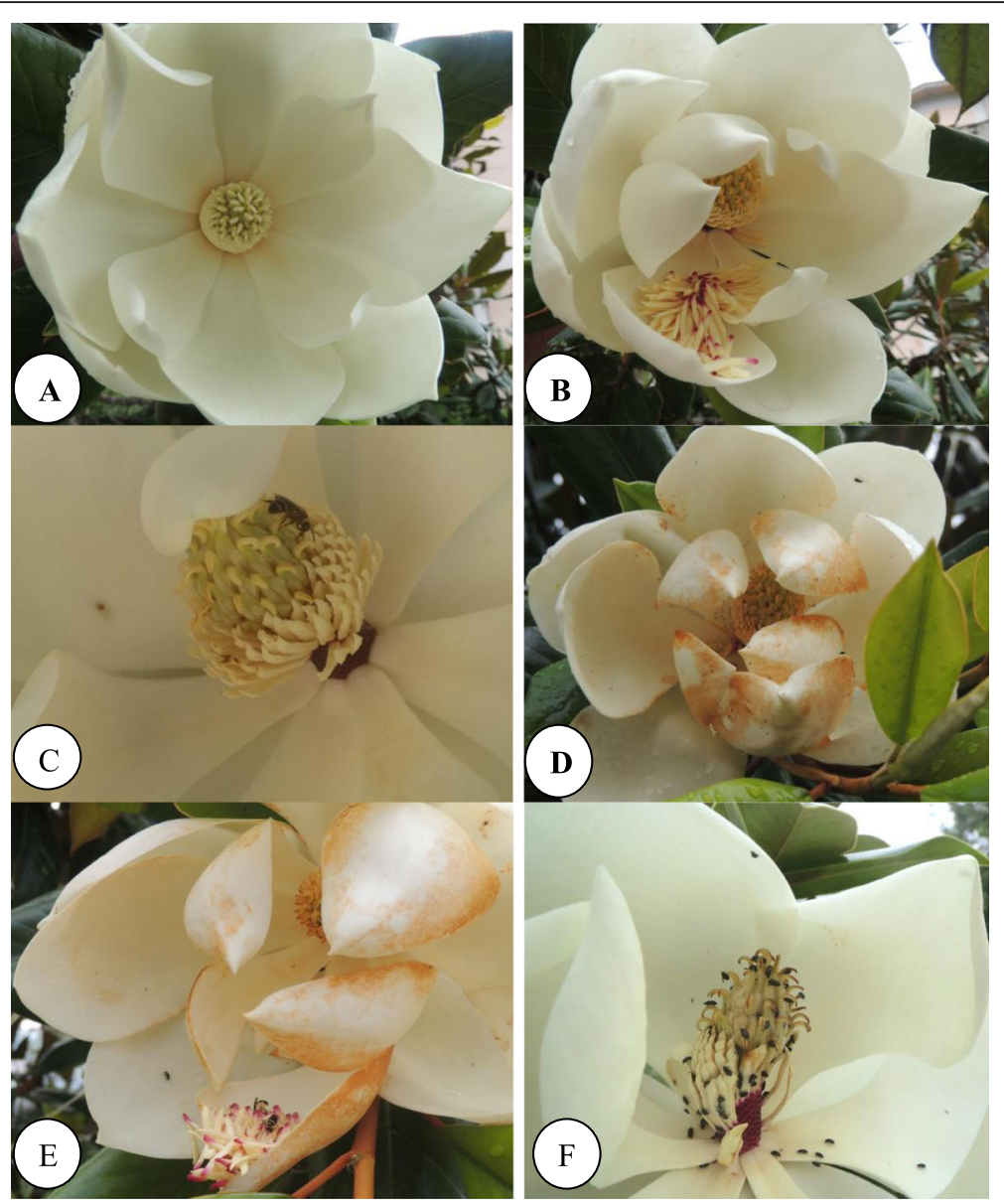

Fig. 1 Dianthesis and activities of floral visitors in M. grandiflora. a First flower opening, protogynous stigmas were exposed. b Second flower opening, anthers have started to dehisce. c Bees (Apis melifera) crawling on stigma resulting self-pollination. $\mathbf{d}$ Numerous thrips collecting dusted pollen from petals. e Two bees (Apis melifera) and beetles collecting pollen from the dehisced anthers over the petals. f Several beetles collecting pollen and feeding stigma secretions resulting selfing

Immediately after flower opening, application of hydrogen peroxide to stigmas resulted in bubbling. It was noticed that stigmas were fleshy and greenish and had ample amount of whitish starch-like substrate over the curved surface in the first flower opening. Stigmas were observed to be yellow and produced a liquefied substance around the time of anther dehiscence in the second flower opening on the second day. Application of hydrogen peroxide continued to elicit bubbling for a period of 2 to 3 days immediately after the opening of the flower. Stigmas became hard, dry and blackish in colour at the end of the third day of anthesis, indicating the termination of receptivity.

\section{Floral visitors and foraging behaviour}

Visitors from five orders (Hymenoptera, Diptera, Coleoptera, Thysanoptera and Araneae) were observed visiting the flowers of M. grandiflora. The 1408 pollinators observed on 32 flowers in the year 2015 comprised bees (6.9\%), beetles (13.2\%), thrips $(78.2 \%)$, flies $(0.92 \%)$ and spiders $(0.64 \%)$. The most abundant pollinator observed in the reproductive year 2016 were bees (6.6\%), beetles (14.4\%), thrips (76.8\%), flies (1.21\%) and spiders (0.87\%), out of the 1153 insects recorded from 29 flowers. The flowers received a high frequency of pollinators on the second day after flower opening, which was concomitant with anther dehiscence at 09:00-12:00 of the day and very rarely in the evening (Table 2). The number of visits and insect activity climaxed at about 11:00-12:00. While visiting flowers bees were dusted with pollen and did the transfer of pollen from anthers to stigma (Fig.1c). At most, 4 bees have visited a flower at a single time and the duration of one single visit varied from $30 \mathrm{~s}$ to 7.5 min within a flower. Bees usually packed the pollen into their hind legs with the help of plumose, while sometimes they deliberately unloaded the pollen, throwing it down while cleaning themselves. Bees collected pollen from the dropped anthers resting on petals and the frequently moved back and forth to search for new anthers (Fig. 1e). We observed that beetles crawled on the receptacle and sucked stigmatic exudates in day-1 flowers, 
Table 1 Chronological events in reproductive stages of M. grandiflora

\begin{tabular}{|c|c|c|}
\hline Stages & $\begin{array}{l}\text { Average duration from bud initiation } \\
\text { in days (June-October) }\end{array}$ & Characteristics \\
\hline $\begin{array}{l}\text { 1st flower bud } \\
\text { initiation }\end{array}$ & 0 days & Flower bud is enclosed by fused hairy three tepals, brownish in colour \\
\hline Tepal removal & $17.5 \pm 1.5$ days & Tepals were shed naturally; candle-shaped crimson white flower bud left \\
\hline $\begin{array}{l}\text { First flower } \\
\text { opening }\end{array}$ & $22 \pm 1$ days & Petals become enlarged; cup-shape corolla, candle-shaped stigma is visible \\
\hline $\begin{array}{l}\text { Stigma } \\
\text { receptivity }\end{array}$ & $22 \pm 1$ days & Stigma is whitish in colour; curved shape, high starch content \\
\hline Flower closing & $22 \pm 1$ days & Flower completely closed \\
\hline $\begin{array}{l}\text { Floral visitors } \\
\text { availability }\end{array}$ & $22 \pm 1$ days & Bees, beetles and thrips are dominant \\
\hline $\begin{array}{l}\text { Second flower } \\
\text { opening }\end{array}$ & $23 \pm 1$ days & Stigma contains ample amount of secretory substance, yellowish in colour \\
\hline $\begin{array}{l}\text { Anther } \\
\text { dehiscence }\end{array}$ & $23 \pm 1$ days & Anthers start to dehisce from periphery \\
\hline $\begin{array}{l}\text { Petals begin to } \\
\text { drop }\end{array}$ & $27 \pm 1$ days & $\begin{array}{l}\text { Petals start to decay and turn darkish yellowish in colour; stigma turned darkish; retained } \\
\text { the remnants of stamen attachment below the candle-shaped stigma }\end{array}$ \\
\hline Fruit formation & $41 \pm 1$ days & Swelling of the candle-shaped stalk of stigma \\
\hline $\begin{array}{l}\text { Fruits start to } \\
\text { dehisce }\end{array}$ & $75 \pm 1$ days & Dehiscence start from the tip of the fruit; fruit is green to reddish in colour \\
\hline
\end{tabular}

could be seen feeding on pollen in day- 2 flowers as the anther dehisced and performing selfing (Fig. 1f). Flies usually settled on receptacles, basking in the sunshine or feeding on the stigmatic secretion, but they rarely collected pollen. The thrips usually rested in the petals rather than on the pollen-receptive stigmas and appear to be unimportant in the pollination of M. grandiflora (Fig. 1d). Spiders were mostly waited for prey and damaged the petals, but did not touch any of essential whorls.

\section{Pollinator-mediated self-pollination (PMS)}

A total of 61 flowers were used to examine pollinatormediated self-pollination in an isolated tree of $M$. grandiflora during the reproductive years 2015 and 2016 .
Fruit set and seed set in the absence of potential mates must result from PMS. Percent fruit set (\% of the number of fruits/number of flowers) was $100 \%$. The fruit was hard and aggregate and each ovary had the potential to produce a maximum of two seeds. The mean number of ovules was $128.5 \pm 3.1$ per flower. There was no significant difference between years for the number of ovules per flower $(t=0.1448, \mathrm{df}=38, p>0.8856)$. An average seed production per fruit was $25.9 \pm 4.9$. A comparison of seed set between 2015 and 2016 indicated that seed set per fruit did not significantly differ $(t=0.2619$, df $=$ $38, p>0.7947$ ). The mean reproductive capacity (\% of number of seeds/ovules per flower) in the absence of potential mates in two subsequent reproductive years was

Table 2 Number of insects per order visiting Magnolia grandiflora flowers (2015-2016)

\begin{tabular}{|c|c|c|c|c|c|c|c|c|}
\hline \multirow[t]{2}{*}{ Order/Species } & \multicolumn{2}{|c|}{ Total number } & \multirow[t]{2}{*}{ Range } & \multirow{2}{*}{$\begin{array}{l}\text { Mean } \\
\text { number/ } \\
\text { flower }\end{array}$} & \multicolumn{2}{|c|}{ Percentage } & \multirow{2}{*}{$\begin{array}{l}\text { Time of } \\
\text { observation }\end{array}$} & \multirow{2}{*}{$\begin{array}{l}\text { Maximum } \\
\text { duration } \\
\text { of a single } \\
\text { visit }\end{array}$} \\
\hline & 2015 & 2016 & & & 2015 & 2016 & & \\
\hline \multicolumn{9}{|l|}{ Hymenoptera } \\
\hline Apis melifera & 98 & 76 & $3-5$ & 4 & 6.96 & 6.59 & $8 \mathrm{am}-12: 30 \mathrm{pm}$ & $7.5 \mathrm{~min}$ \\
\hline \multicolumn{9}{|l|}{ Coleoptera } \\
\hline Flower beetle & 186 & 167 & $4-10$ & 5 & 13.2 & 14.4 & $8 \mathrm{am}-12: 30 \mathrm{pm}$ & Constant \\
\hline \multicolumn{9}{|l|}{ Diptera } \\
\hline Fly & 13 & 14 & 1 & 1 & 0.92 & 1.21 & $8 \mathrm{am}-12: 30 \mathrm{pm}$ & $1.5 \mathrm{~min}$ \\
\hline \multicolumn{9}{|l|}{ Thysanoptera } \\
\hline Thripidae & 1102 & 886 & $0-170$ & 39 & 78.2 & 76.8 & & Constant \\
\hline \multicolumn{9}{|l|}{ Araneae } \\
\hline Spider & 9 & 10 & 2 & 1 & 0.64 & 0.87 & $10 \mathrm{am}-11: 30 \mathrm{am}$ & Constant \\
\hline
\end{tabular}


$20.2 \pm 3.9$ and $19.8 \pm 3.2$. The seed set per ovule between years did not differ significantly $(t=0.3105, \mathrm{df}=$ $38, p>0.3789$ ). The relative pollinator abundance and seed set per ovule was similar in two consecutive periods. There was a significant positive correlation between number of bees and beetles that visited the flower and seed set per ovule (bees: $r=0.5099, p=0.0007$, beetles: $r=0.7159, p=0.00001$, Fig. 2a, b), indicating that bees and beetles were an important pollinators for performing self-pollination in M. grandiflora. There was no relationship between the number of flies visited/flower and reproductive capacity $(r=0.3729, p>0.3919)$. A negative and significant correlation $(r=-0.3206, p=$ $0.0437)$ was observed between abundance of thrips visited/flower and reproductive capacity (Fig. 2c). However, the effect of spiders was non-significant $(r=-0.101, p>$ 0.5352 ), indicating that spiders and thrips were unimportant for pollen transfer in M. grandiflora. Fruit derived from PMS varied in size, colour and structure, indicating that the external environmental condition also affect the development of the fruits.

\section{Discussion}

We described the reproductive behaviour of an individual tree of M. grandiflora in such a condition where potential mates were absent. $M$. grandiflora is similar to most other members of the Magnoliaceae in having protogynous, selfcompatible and beetle-pollinated breeding system (Thien 1974; Gibbs et al. 1977; Kikuzawa and Mizui 1990; Hirayama et al. 2005). Flowering began in late June and continued with sporadic breaks until August. At most, 5 flowers were developed at a time on the entire tree. The tree produced approximately 32 flowers in 2015 and 29 flowers in 2016, and all flowers set fruit. Flowers were functional for 2-3 days with maximum pollen transferred on 2 days onwards during which anthers were dehisced. Flowers of M. grandiflora possess a suite of traits that attract pollinators, in particular bees and beetles: flowers emit a strong fruity fragrance, petals
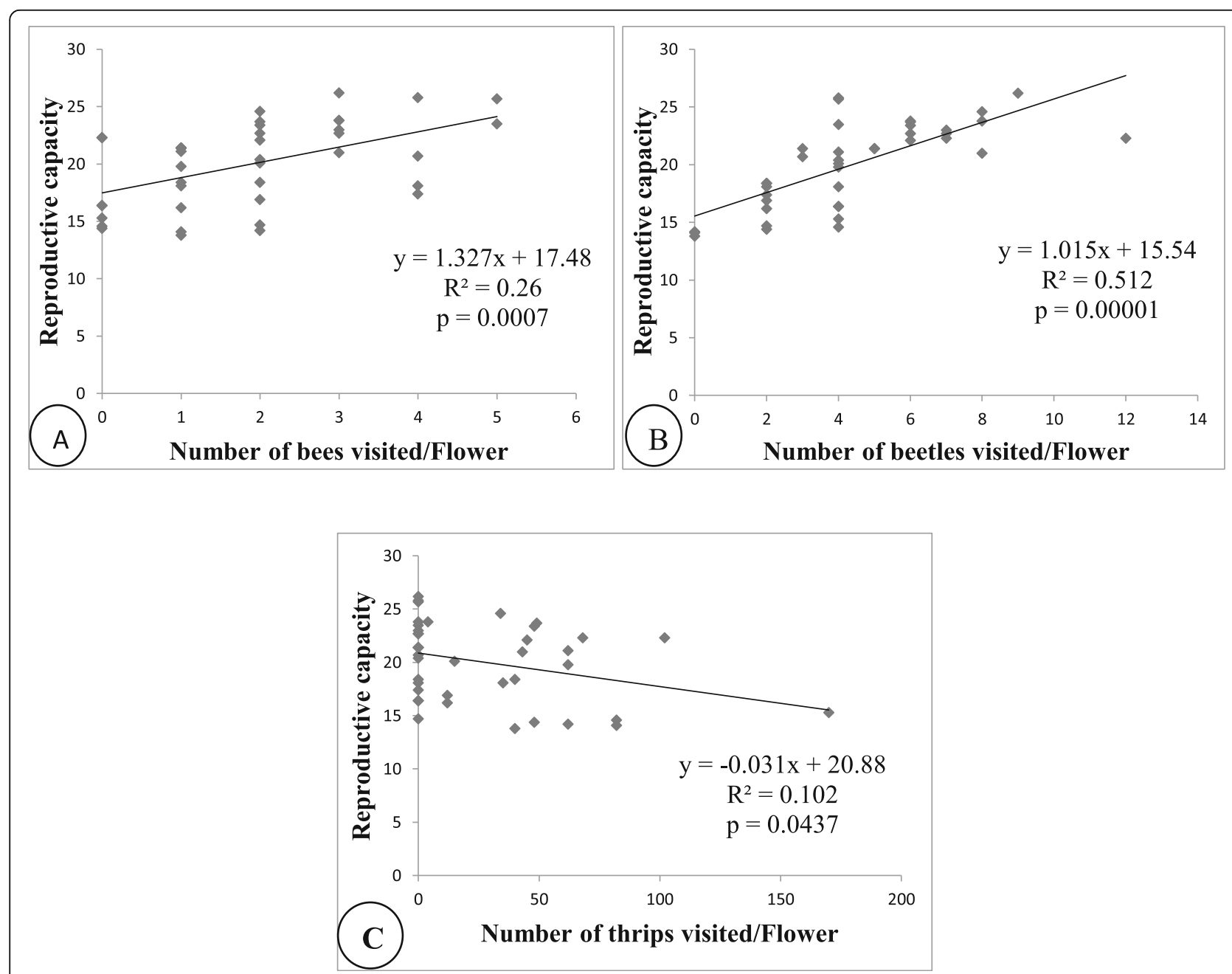

Fig. 2 Relationship between number of visits per flower and reproductive capacity in M. grandiflora for different visitors. a Bees (Hymenoptera), b beetles (Coleoptera) and $\mathbf{c}$ thrips (Thysanoptera) 
represent a specialized food tissue, flowers are thermogenic and copious pollen is produced. The large unspecialised flowers of Magnolia are assumed to be related with the unspecialised "mess and soil" pollination syndrome of beetles (Faegri and van der Pijl 1979). The large petals likely enhance flower attractiveness. Closed petals preserve pollen, stigma secretions, etc. for beetles. Partially closed flowers were not considered traps for insects, particularly for beetles, which are capable of entering or exiting via the smallest opening. Bees try unsuccessfully to enter unopened flowers in M. grandiflora (Thien 1974).

Pollen production per flower in the present study was $5,152,289 \pm 285,094$, which was much lower than that $(58,000,000$ per flower) of the study conducted by Allain et al. (1999). Pollen production in a species is affected by genotype, size class, vigour, climate, site and meteorological phenomena such as warmth, dryness and sunshine during the formation of flower primordial in the previous year, favourable or unfavourable precipitation during the vegetative growing season, sunshine prior to pollination and wind direction (Khanduri and Sukumaran 2019; Potter and Rowley 1960; Erdetman 1943; Hansen 1949).

It was observed that $M$. grandiflora flower had generalized pollinator relationships. Visitors from five orders such as Coleoptera, Hymenoptera, Diptera, Thysanoptera and Araneae were found to be the major floral visitors. Yasukawa et a1. (1992) studied eight Magnolia taxa in Japan and concluded that Diptera (flies), Hymenoptera (bees etc.) and Coleoptera (beetles) were all pollinators of Magnolia. However, several researchers reported that Coleopterans are considered the primary pollinators of various Magnolia genera and species of Magnolia (Baker and Hurd 1968; Faegri and van der Pijl 1979; Thien 1974; Gibbs et al. 1977; Allain et al. 1999; Losada 2014).

We found that the flowers of $M$. grandiflora could be considered to be a classic example of beetle pollination with features such as copious pollen production, protogyny, bowlshape, emitting an intense odour and closing their petals in the evening. Beetles could crawl on receptive receptacles and pollinate most of the stigmas. However, pollinator investigations showed that beetles were not the exclusive pollinators. We observed that insect activity varies with both microclimatic conditions and availability of rewards. The maximum number of floral visitors observed from day-2 flowers confirming that pollen is the primary food rewards to floral visitors in M. grandiflora. Yasukawa et al. (1992) reported that pollen is the major source of nitrogen for insects. In accordance with previous studies, petals, stigma and gynoecium secretions in Magnolia species may also serve as food for insect visitors (Heiser 1962; Thien 1974; Yasukawa et al. 1992). The large stigmatic drops in flowers of M. macrophylla and M. ashei are eaten by bees, beetles and other insects (Thien et al. 1995; Latimer 1994).
The role of bees in pollination of Magnolia is controversial (Yasukawa et al. 1992). Our study shows that honeybees were one of the most frequent visitors of the flower. They visited the flower in both female and male phases of the flower. Other researchers have also concluded that honeybees play a significant role in the pollination of M. grandiflora flowers (Heiser 1962; Thien 1974; Yasukawa et al. 1992; Allain et al. 1999; Losada 2014). Bees tended to collect pollen grains rather than nectar which may be due to the high usage benefit of pollen as a potential food reward in Magnolia.

Even in the absence of mates, all flowers set fruit and up to $20 \%$ of ovules set seed. However, the seed set following cross-pollination in $M$. grandiflora varied between 27 and $55 \%$ depending on peak time of pistillate flower receptivity and the natural pollination averaged $34 \%$ seed set (Allain et al. 1999). These results demonstrate that PMS should be beneficial ensuring fruit set and seed set when outcrossing mates are scarce or absent. Such conditions are common in population of $M$. grandiflora on the Indian subcontinent as it is widely planted for ornamental purpose; hence, individual plants can be isolated. A meta-analysis (Aguilar et al. 2006) reported that a decrease in the size and an increase in the isolation of plant populations resulting from habitat fragmentation could locally reduce the reproductive success of plants. Indeed, small and/or sparse and isolated plant populations with small floral display sizes may provide little attraction or reward for pollinators (Kunin 1997; Dauber et al. 2010). Indirect evidence from some studies of the effect of plant abundance on fecundity suggests that mate limitation may generally be more important than reduced pollinator visitation in reducing cross-pollen receipt of isolated individuals (Kunin 1993; Duncan et al. 2004; Elam et al. 2007).

Autonomous selfing should be beneficial in species that commonly face large seasonal or inter-annual fluctuations in pollinator visits because it removes dependence on an insect vector, thus providing reproductive assurance (Kropf and Renner 2008). One of the main reasons for this is that smaller, sparser and more isolated patches of plants are less likely to be discovered by animal pollinators and, if discovered, are less profitable for foraging (Sih and Baltus 1987; Feinsinger et al. 1991; Agren 1996). The ability to self-fertilize generally reduces or eliminates pollen limitation (Kalisz et al. 2004; Knight et al. 2005; Brys et al. 2011) and provides reproductive assurance (Morgan and Wilson 2005; Kennedy and Elle 2008). We found that there was no significant difference in the relative abundance of floral visitors and seed set per fruit in the 2 reproductive years. Thus, the relative effectiveness of pollinator supporting selfpollination remains the same during the study period. 
In Magnolia, self-pollination may occur autonomously or be mediated by pollinator foraging either within the flower (PMS) or between flowers (geitonogamy). Most studies investigating the sources of self-pollination have found that geitonogamy was responsible for much of the total selfing (Schoen and Lloyd 1992; Eckert 2000). In $M$. grandiflora, we found that flowers did not autonomously self-pollinate due to protogyny (female function prior to male function) and herkogamy (separation in sexual function in space). However, there is a chance of geitonogamy to happen, if more than two flowers open together or if one flower opens 1 day before another flower. We conclude that seed set in individual trees of $M$. grandiflora occurs through pollinator-mediated selfpollination which ensures reproductive assurance when potential mates are scarce or pollen limitation. Numerous studies reported that pollinator-mediated selfing may be beneficial in species occurring in sparse populations where flowering conspecifics are scarce, but pollinators are present (Lloyd 1979, 1992; Goodwillie et al. 2005). Pollinator-mediated self-pollination is likely the consequence of pollinator foraging. Our results suggest that there was a strong positive correlation between numbers of bees and beetles that visited the flower and total seed output, indicating bees and beetles play a potential role in self-pollinating $M$. grandiflora. The weak or moderate negative correlations between numbers of flies, spiders and thrips visited/flower and seed set per ovule indicates that they are less efficient in intra-flower pollination. The effectiveness of pollinators that cause selfpollination in self-compatible plants likely vary enormously, depending on the kind and amount of floral rewards, movement of the floral visitors, the time they spend on each flower, floral biology and microclimatic conditions. In small populations, it has been shown that pollinators tend to visit an increasing number of flowers within an individual (Kunin 1993; Ghazoul et al. 1998); pollinators may adapt their foraging behaviour to maximize resource use and nutrient uptake (Thomson 1981). Under such circumstances, pollinators are likely to forage longer on the same plant (de Jong et al. 1993), thereby increasing the amount of self-pollination (Karron et al. 2009). Increased foraging within a plant could compensate, according to the strength of inbreeding depression, for the lack of mate availability and conspecific pollen (Duncan et al. 2004; Wagenius 2006; Campbell and Husband 2007).

\section{Conclusions}

Our results provide empirical evidence that pollinatormediated self-pollination in M. grandiflora confers reproductive assurance when potential mates were scarce or absent. It was well established that pollinatormediated self-pollination not only mitigated the effect of decreased mate availability but also increased the fecundity of individual trees in geographically isolated locations. The effectiveness of floral visitors performing self-pollination likely varies with its type (e.g. generalist vs specialist), density, mobility and pollen-carrying capacity, as well as floral rewards, potential mate availability and synchronization of flowering within and between conspecifics. Long-term studies on reproduction in geographically isolated plants and detailed knowledge of floral specialization are required to understand the local adaptation of pollinators to flower features. Besides, we could gain a better insight into whether PMS enhances population viability and reduces extinction.

\section{Acknowledgements}

The authors are highly grateful to both the anonymous reviewers of the earlier draft of this manuscript for their valuable comments and suggestions, which have improved the manuscript immensely.

\section{Authors' contributions}

AS and VPK conceived the study, set up the experiment and conducted field work. AS drafted the initial manuscript. VPK and CMS revised the drafts. CMS helped in designing the field experiment. All authors read and approved the manuscript.

\section{Funding}

One of the authors VPK is thankful to Department of Biotechnology (DBT), New Delhi, for financial assistance.

\section{Availability of data and materials}

The datasets used and/or analysed during the current study are available from the corresponding author on reasonable request.

Ethics approval and consent to participate

No existing conflicts of interest.

\section{Consent for publication}

NA

\section{Competing interests}

The authors declare that they have no competing interests.

Received: 29 March 2020 Accepted: 17 August 2020

Published online: 31 August 2020

\section{References}

Agren J (1996) Population size, pollinator limitation, and seed set in the selfincompatible herb Lythrum salicaria. Ecology 77:1779-1790

Aguilar R, Ashworth L, Galetto L, Aizen MA (2006) Plant reproductive susceptibility to habitat fragmentation: review and synthesis through a metaanalysis. Ecol Lett 9:968-980

Allain KL, Zavada MS, Matthews GD (1999) The reproductive biology of Magnolia grandiflora. Rhodora 101:143-162

Baker HG (1955) Self-compatibility and establishment after 'long-distance' dispersal. Evolution 9:347-349

Baker HG, Hurd PD (1968) Intrafloral ecology. Annu Rev Ecol Syst 13:385-414

Barrett SCH (2002) The evolution of plant sexual diversity. Nat Rev Genet 3:274284

Brys R, de Crop E, Hoffmann M, Jacquemyn H (2011) Importance of autonomous selfing is inversely related to population size and pollinator availability in a monocarpic plant. Am J Bot 98:1834-1840

Campbell LG, Husband BC (2007) Small populations are mate-poor but pollinator-rich in a rare, self-incompatible plant, Hymenoxys herbacea (Asteraceae). New Phytol 174:915-925

Carrington ME, Gottfried TD, Mullahey JJ (2003) Pollination biology of saw palmetto (Serenoa repens) in Southwestern Florida. Palms 47:95-103

Charlesworth D (2006) Evolution of plant breeding systems. Curr Biol 16:726-735

Chen Y, Chen G, Yang J, Sun W (2016) Reproductive biology of Magnolia sinica (Magnoliaecea), a threatened species with extremely small populations in Yunnan, China. Plant Divers 38:253-258 
Cronquist A (1981) An Integrated System of Classification of Flowering Plants. Columbia University Press, NY

Darwin CR (1876) The effects of cross and self fertilisation in the vegetable kingdom. Murray, London

Dauber J, Biesmeijer JC, Gabriel D, Kunin WE, Lamborn E, Meyer B, Nielsen A, Potts SG, Roberts SPM, Sober V, Settele J, Steffan-Dewenter I, Stout JC, Teder T, Tscheulin T, Vivarelli D, Petanidou T (2010) Effects of patch size and density on flower visitation and seed set of wild plants: a pan-European approach. J Ecol 98:188-196

Dieringer G, Cabrera-R L, Lara M, Loya L, Reyes-Castillo P (1999) Beetle pollination and floral thermogenicity in Magnolia tamaulipana (Magnoliaceae). Int J Plant Sci 160:64-71

Duncan DH, Nicotra AB, Wood JT, Cunningham SA (2004) Plant isolation reduces outcross pollen receipt in a partially self-compatible herb. J Ecol 92:977-985

Eardtman G (1943) An Introduction to Pollen Analysis. Cronica Botanica. Massachusetts, Waltham

Eckert CG (2000) Contributions of autogamy and geitonogamy to self-fertilization in a mass-flowering, clonal plant. Ecology 81:532-542

Elam DR, Ridley CE, Goodell K, Ellstrand NC (2007) Population size and relatedness accept fitness of a self-incompatible invasive plant. Proc Natl Acad Sci 104:549-552

Faegri K, van der Pijl L (1979) The principles of pollination ecology, 3rd edn. Pergamon Press, Oxford, 248p

Feinsinger P, Tiebout HM, Young BE (1991) Do tropical bird-pollinated plants exhibit density-dependent interaction? Field experiments. Ecology 72:19531963

Fisher RA (1941) Average excess and average effect of a gene substitution. Ann Eugenics 11:53-63

Ghazoul J, Liston KA, Boyle TJB (1998) Disturbance-induced density-dependent seed set in Shorea siamensis (Dipterocarpaceae), a tropical forest tree. J Ecol $86: 462-473$

Gibbs PE, Semir J, Da Cruz ND (1977) Floral biology of Talauma ovata St. Hil. (Magnoliaceae). Ciên Cult 29:1436-1441

Goodwillie C, Kalisz S, Eckert CG (2005) The evolutionary enigma of mixed mating systems in plants: Occurrence, theoretical explanations, and empirical evidence. Annu Rev Ecol Evol Syts 36:47-79

Hansen HP (1949) Pollen contents of mass polsters in relation to forest composition. Am Midl Nat 42:473-479

Harder LD, Barrett SCH (1995) Mating cost of large floral displays in hermaphrodite plants. Nature 373:512-515

Heiser CB (1962) Some observations on pollination and compatibility in Magnolia. Proc Indian Acad Sci 72:259-266

Hirayama K, Ishida K, Tomaru N (2005) Effects of pollen shortage and selfpollination on seed production of an endangered tree, Magnolia stellata. Ann Bot 95:1009-1015

Ishida K (1996) Beetle pollination of Magnolia praecocissima var. borealis. Plant Spec Biol 11:199-206

de Jong TJ, Waser NM, Klinkhamer PGL (1993) Geitonogamy: the neglected side of selfing. Trends Ecol Evol 8:321-325

Kalisz S, Vogler DW, Hanley KM (2004) Context-dependent autonomous selffertilization yields reproductive assurance and mixed mating. Nature 430: 884-887

Kameneva LA, Koksheeva IM (2013) Reproductive biology of seven taxa of Magnolia L. in the south of Russian far east. Bangl J Plant Taxon 20:163-170

Karron JD, Holmquist KG, Flanagan RJ, Mitchell RJ (2009) Pollinator visitation patterns strongly influence among-flower variation in selfing rate. Ann Bot 103:1379-1383

Kennedy BF, Elle E (2008) The reproductive assurance benefit of selfing: importance of flower size and population size. Oecologia 155:469-477

Khanduri VP (2012) Annual variation in floral phenology and pollen production in a 25-year-old plantation of Tectona grandis. Nord J Bot 30:82-89

Khanduri VP, Sukumaran A (2019) Pollen dispersion in Myrica esculenta (Myricaceae): a dioecious anemophilous tree species of Himalaya. Aerobiologia 35:583-591

Khanduri VP, Sukumaran A, Sharma CM (2019) Male-skewed sex ratio in Myrica esculenta: A dioecious tree species. Trees 33:1157-1165

Kikuzawa KM, Mizui N (1990) Flowering and fruiting phenology of Magnolia hypoleuca. Plant Spec Biol 5:255-261

Knight TM, Steets JA, Vamosi JC, Mazer SJ, Burd M, Campbell DR, Dudash MR, Johnston MO, Mitchell RJ, Ashman TL (2005) Pollen limitation of plant reproduction: pattern and process. Annu Rev Ecol Evol Syst 36:467-497
Kropf M, Renner SS (2008) Pollinator-mediated selfing in two deceptive orchids and a review of pollinium tracking studies addressing geitonogamy. Oecologia 155:497-508

Kunin WE (1993) Sex and the single mustard. Population-density and pollinator behavior effects on seed-set. Ecology 74:2145-2160

Kunin WE (1997) Population size and density effects in pollination: pollinator foraging and plant reproductive success in experimental arrays of Brassica kaber. J Ecol 85:225-234

Latimer SD (1994) Magnolia ashei (Magnoliaceae): Biology and Conservation of an Endangered Species. Doctoral Dissertation, Tulane University, New Orleans

Lloyd DG (1979) Some reproductive factors affecting the selection of selffertilization in plants. Am Nat 113:67-79

Lloyd DG (1992) Self- and cross-fertilization in plants. II. The selection of selffertilization. Int J Plant Sci 153:370-380

Lloyd DG, Schoen DJ (1992) Self-fertilization and cross-fertilization in plants. I. Functional dimensions. Int J Plant Sci 153:358-369

Longhurst AR (1955) Evolution of the Notostraca. Evolution 9:84-86

Losada JM (2014) Magnolia virginiana: ephemeral courting for millions of years. Arnoldia 71:19-27

Morgan MT, Wilson WG (2005) Self-fertilization and the escape from pollen limitation in variable pollination environments. Evolution 59:1143-1148

Potter LD, Rowley J (1960) Pollen rain and vegetation, San Augustin Plains, New Mexico. Bot Gaz 122:1-25

Schoen DJ, Lloyd DG (1992) Self- and cross-fertilization in plants. III. Methods of studying modes and functional aspects of fertilization. Int J Plant Sci 153 381-393

Sih A, Baltus MS (1987) Patch size, pollinator behavior, and pollinator limitation in catnip. Ecology 68:1679-1690

Stebbins GL (1950) Variation and evolution in plants. Columbia University Press, New York

Thien LB (1974) Floral biology of Magnolia. Am J Bot 61:1037-1045

Thien LB, Sawano S, Axuma H, Latimer S, Devall MS, Rosso S, Elakovich S, Gray VR, Jobes D (1995) Fluorescent Magnolia flowers. Plant Spec Biol 10:61-64

Thomson JD (1981) Spatial and temporal components of resource assessment by flower-feeding insects. J Anim Ecol 50:49-59

Vaughton G, Ramsey M (2010) Pollinator-mediated selfing erodes the flexibility of the best-of-both-worlds mating strategy in Bulbine vagans. Funct Ecol 24 374-382

Wagenius S (2006) Scale dependence of reproductive failure in fragmented Echinacea populations. Ecology 87:931-941

Yasukawa S, Kato H, Yamaoka R, Tanaka H, Arai H, Kawano S (1992) Reproductive and pollination biology of Magnolia and its allied genera (Magnoliaceae)-I. Floral volatiles of several Magnolia and Michelia species and their roles in attracting insects. Plant Spec Biol 7:121-140

\section{Publisher's Note}

Springer Nature remains neutral with regard to jurisdictional claims in published maps and institutional affiliations.

\section{Submit your manuscript to a SpringerOpen ${ }^{\circ}$ journal and benefit from:}

- Convenient online submission

- Rigorous peer review

- Open access: articles freely available online

- High visibility within the field

- Retaining the copyright to your article

Submit your next manuscript at $>$ springeropen.com 